\title{
Comorbidity and dementia: a scoping review of the literature
}

\author{
Frances Bunn 1*, Anne-Marie Burn', Claire Goodman ${ }^{1}$, Greta Rait ${ }^{2}$, Sam Norton ${ }^{3}$, Louise Robinson 4 , \\ Johan Schoeman ${ }^{5}$ and Carol Brayne ${ }^{6}$
}

\begin{abstract}
Background: Evidence suggests that amongst people with dementia there is a high prevalence of comorbid medical conditions and related complaints. The presence of dementia may complicate clinical care for other conditions and undermine a patient's ability to manage a chronic condition. The aim of this study was to scope the extent, range and nature of research activity around dementia and comorbidity.

Methods: We undertook a scoping review including all types of research relating to the prevalence of comorbidities in people with dementia; current systems, structures and other issues relating to service organisation and delivery; patient and carer experiences; and the experiences and attitudes of service providers. We searched AMED, Cochrane Library, CINAHL, PubMed, NHS Evidence, Scopus, Google Scholar (searched 2012, Pubmed updated 2013), checked reference lists and performed citation searches on PubMed and Google Scholar (ongoing to February 2014).
\end{abstract}

Results: We included 54 primary studies, eight reviews and three guidelines. Much of the available literature relates to the prevalence of comorbidities in people with dementia or issues around quality of care. Less is known about service organisation and delivery or the views and experiences of people with dementia and their family carers. There is some evidence that people with dementia did not have the same access to treatment and monitoring for conditions such as visual impairment and diabetes as those with similar comorbidities but without dementia.

Conclusions: The prevalence of comorbid conditions in people with dementia is high. Whilst current evidence suggests that people with dementia may have poorer access to services the reasons for this are not clear. There is a need for more research looking at the ways in which having dementia impacts on clinical care for other conditions and how the process of care and different services are adapting to the needs of people with dementia and comorbidity. People with dementia should be included in the debate about the management of comorbidities in older populations and there needs to be greater consideration given to including them in studies that focus on age-related healthcare issues.

Keywords: Dementia, Comorbidity, Diabetes, Stroke, Visual impairment, Scoping review

\section{Background}

World-wide there are an estimated 35.6 million people with dementia. By 2050 it has been estimated that this number will rise to more than 115 million [1]. Dementia is primarily a disease of old age and it often coexists with other conditions of old age. Evidence suggests that amongst people with dementia there is a high

\footnotetext{
* Correspondence: f.bunn@herts.ac.uk

${ }^{1}$ Centre for Research in Primary and Community Care, University of Hertfordshire, College Lane, Hatfield, Hertfordshire AL10 9AB, UK Full list of author information is available at the end of the article
}

prevalence of comorbid medical conditions and related complaints [2-5]. In addition, there is evidence to support an association between the dementia syndrome including Alzheimer's disease and cardiovascular risk factors, such as hypertension and hypercholesterolaemia [6,7].

Comorbidity amongst people with dementia presents particular challenges for primary and secondary care. Certain comorbid medical conditions may exacerbate the progression of dementia [8]. For example, cognitive decline may be accelerated in older people with type 2 diabetes $[9,10]$. Moreover, the presence of dementia may 
adversely affect and complicate the clinical care of other conditions and be a key factor in how patients' needs are anticipated and specialist and emergency services are used $[11,12]$. It may also undermine patients' abilities to selfmanage chronic conditions and engage in health maintenance activities [13]. Despite this, little is known about the effects of comorbidity on processes and quality of care, patient experience, or how services are adapting to address the particular needs of this population [14].

A review of qualitative research on the experience of diagnosis and treatment of dementia [15] found very little evidence relating to the experiences of people diagnosed with dementia who have an accompanying comorbid condition. There is also a lack of research on patients' views on the ways in which multiple conditions affect their health, well-being and clinical care [16]. The aim of this review was to identify the extent, range and nature of research activity relating to dementia and comorbidity, in particular the prevalence of co-morbidity amongst people with dementia, systems and structures that currently exist for the care of people with dementia who have comorbid medical conditions, and the experiences of people with dementia who have comorbid medical conditions and their family carers.

\section{Methods}

The scoping review was guided by Arksey and O'Malley's methodological framework $[17,18]$ which includes: identifying the research question; searching for relevant studies; selecting studies; charting the data and collating and summarising and reporting the results. This approach allowed us to incorporate a range of study designs and address questions beyond those related to treatment efficacy. Whilst the scoping review has a number of similarities to a systematic review it does not typically involve quality assessment and findings are reported in a narrative format $[19,20]$. The inclusion criteria and methods for the review were pre-specified in a protocol [21]. The protocol was externally peer reviewed as part of the National Institute for Health Research (NIHR) funding process.

\section{Identifying the research question Inclusion criteria}

We included studies involving people with dementia who had an additional comorbid health condition. Although we included all types of comorbidities there was a particular focus on three exemplar comorbid medical conditions; diabetes, stroke and visual impairment. These three conditions were chosen because they are common in older people, generally involve some form of external monitoring and require collaboration between primary and secondary care. Moreover, they may exacerbate or influence the progression of dementia and management of these conditions; in particular, self-management is likely to be complicated by the presence of dementia [13]. We focused on community dwelling participants and excluded studies in long term care settings. We looked for studies relating to the prevalence of comorbidities in people with dementia or cognitive impairment; current systems, structures and other issues relating to service organisation and delivery; patient and carer experiences; and the experiences and attitudes of service providers. We included all study types including systematic reviews, randomised controlled trials (RCTs), controlled studies, observational studies and qualitative studies using any recognisable qualitative methodology. In addition, we included non-research items, such as clinical guidelines. We excluded studies disseminated in languages other than English.

\section{Searching for relevant studies}

We searched for a representative range of material which provided an overview of current knowledge and that identified some key examples of developments in the organisation and delivery of care for people with dementia and comorbid conditions. We included published and unpublished literature with no date restrictions. Studies were identified by computerised searches of AMED, Cochrane Library (including CENTRAL, CDSR, DARE, HTA), CINAHL (EBSCO Publishing) (1980 to 2012), PubMed (1950 to 2013), NHS Evidence (searched September 2012) and Scopus (1966 to 2012). The electronic search strategy was developed by an experienced information scientist with input from the project team. An example of the search query for PubMed is given in Table 1. In addition, we employed extensive lateral search techniques, such as checking reference lists, performing key word searches in Google Scholar and using the 'cited by' option in PubMed. We also contacted experts and those with an interest in dementia, such as the Alzheimer's Society, the Thomas Pocklington Trust, Royal National Institute for the Blind, Diabetes UK, the Stroke Association, and the Dementia and Sight Loss Interest Group. Such lateral strategies have been shown to be particularly important for identifying non-randomised studies [22]. The original electronic database searches were conducted in September 2012, with the PubMed search updated in November 2013 and lateral searches updated in February 2014.

\section{Selecting studies and charting the data}

Electronic search results were downloaded into EndNote bibliographic software and, where possible, duplicates deleted. Two authors (FB and $A B$ ) independently screened titles and abstracts identified by the electronic search and applied the selection criteria to potentially relevant papers. Data were extracted by one author using a standardised checklist and checked by a second. Any disagreements were resolved by consensus or by discussion with a third author (CG). Where results of a study were reported in 
Table 1 Search strategy used in PubMed

\begin{tabular}{ll}
\hline Search component & Search terms \\
\hline \#1 Dementia and diabetes & ((Dementia OR Alzheimer OR cognitive impairment OR delirium) AND (Diabetes OR blood glucose self-monitoring) \\
& (Self management OR Self Care OR Self monitoring OR Service delivery OR Service organization OR Activities of daily \\
& living OR Caregivers OR Quality Assessment OR Quality OR Quality Indicators OR Quality of life OR Disease Progression \\
& OR Behaviour OR Impact OR Geriatric Assessment OR Severity of Illness OR Nursing Assessment OR Interprofessional OR \\
& Standard of Care OR Risk Factors OR Treatment outcome OR patient Experience) AND (Humans[Mesh]))
\end{tabular}

\#2 Dementia and stroke

\#3 Dementia and visual
impairment

\section{\#4 Dementia and comorbidity}

(Dementia[ti] OR Alzheimer[ti]) AND (stroke OR cerebrovascular OR CVA OR cerebrovascular disorders) AND (Self management OR Self Care OR Self monitoring OR Service delivery OR Service organization OR Activities of daily living OR Caregivers OR Quality Assessment OR Quality OR Quality Indicators OR Quality of life OR Disease Progression OR Behaviour OR Impact OR Geriatric Assessment OR Severity of Illness OR Nursing Assessment OR Interprofessional OR Standard of Care OR Risk Factors OR Treatment outcome OR patient Experience) AND (Humans[Mesh]))

(Dementia OR Alzheimer OR cognitive impairment OR delirium) AND (Eye diseases OR vision disorders OR Blindness OR visually impaired OR Nystagmus OR retinopathy OR macular degeneration OR glaucoma or cataract) AND (Self management OR Self Care OR Self monitoring OR Service delivery OR Service organization OR Activities of daily living OR Caregivers OR Quality Assessment OR Quality OR Quality Indicators OR Quality of life OR Disease Progression OR Behaviour OR Impact OR Geriatric Assessment OR Severity of IIIness OR Nursing Assessment OR Interprofessional OR Standard of Care OR Risk Factors OR Treatment outcome OR patient Experience)

((Dement*[ti] OR Alzheimer*[ti]) AND ((comorbidity OR co-morbidity OR comorbid OR "other medical conditions" OR "Other chronic disease*" OR multimorbidity[ti] OR multi-morbidity[ti] OR multiple disease*[ti] OR multiple morbid*[ti] OR polypathology[ti] OR associated disease*[ti] OR associated disorder*[ti]) OR co-existence[ti] OR co-existing[ti] OR concomitant[ti] OR co-occurring[ti])) more than one publication, we grouped reports together and marked the publication with the most complete data as the primary reference; the other papers describing the same study were classified as associated papers. Data extracted included type of item (for example, empirical study, review, guideline), aims/research questions, methods, study focus, participants, setting and relevant outcome data (for example, rates of comorbidities, access to treatment, patient and carer views).

\section{Reporting the results}

Studies were grouped into the following categories: 1) prevalence, 2) quality of care, 3) views and experiences (patients, carers and health care professionals) and 4) health service organisation and delivery. All data are reported in a narrative format.

\section{Results}

\section{Description of studies}

We included 74 papers, 65 of which were classified as primary references $[2,5,11,13,23-83]$ and nine as associated papers [84-92]. Study characteristics are summarised in the list below and details of individual studies, including the links between primary and associated papers, in Additional file 1. An overview of the selection process can be seen in Figure 1. We included studies conducted in 12 different countries but $63 \%$ were from the UK and USA; the majority were observational, qualitative or reviews. Participants were predominantly community dwelling (some had mixed samples and included those living in long-term care) and the majority were older than 70; ethnicity was not reported in $55 \%(\mathrm{n}=36)$ of studies. In $60 \%$ of studies $(\mathrm{n}=39)$ participants all had dementia, in
$25 \%(\mathrm{n}=16)$ they had mixed populations including people with dementia, cognitive impairment and delirium and in $15 \%(\mathrm{n}=10)$ they had cognitive impairment. A total of 39 studies $(60 \%)$ focused on a single comorbidity and the rest on more than one comorbidity or general comorbidity/ multimorbidity (for example papers relating to the experiences of people with dementia in acute hospitals). We found more evidence relating to diabetes or visual impairment than relating to stroke, and most of the evidence related to the prevalence and quality of care with less on service organisation and delivery or views and experiences of patients, carers or health care professionals.

\section{Overview of study characteristics}

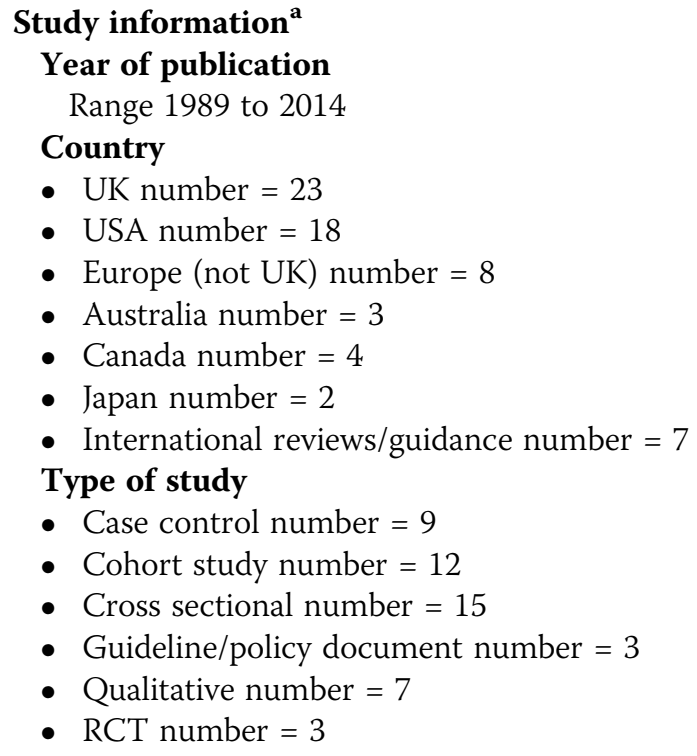




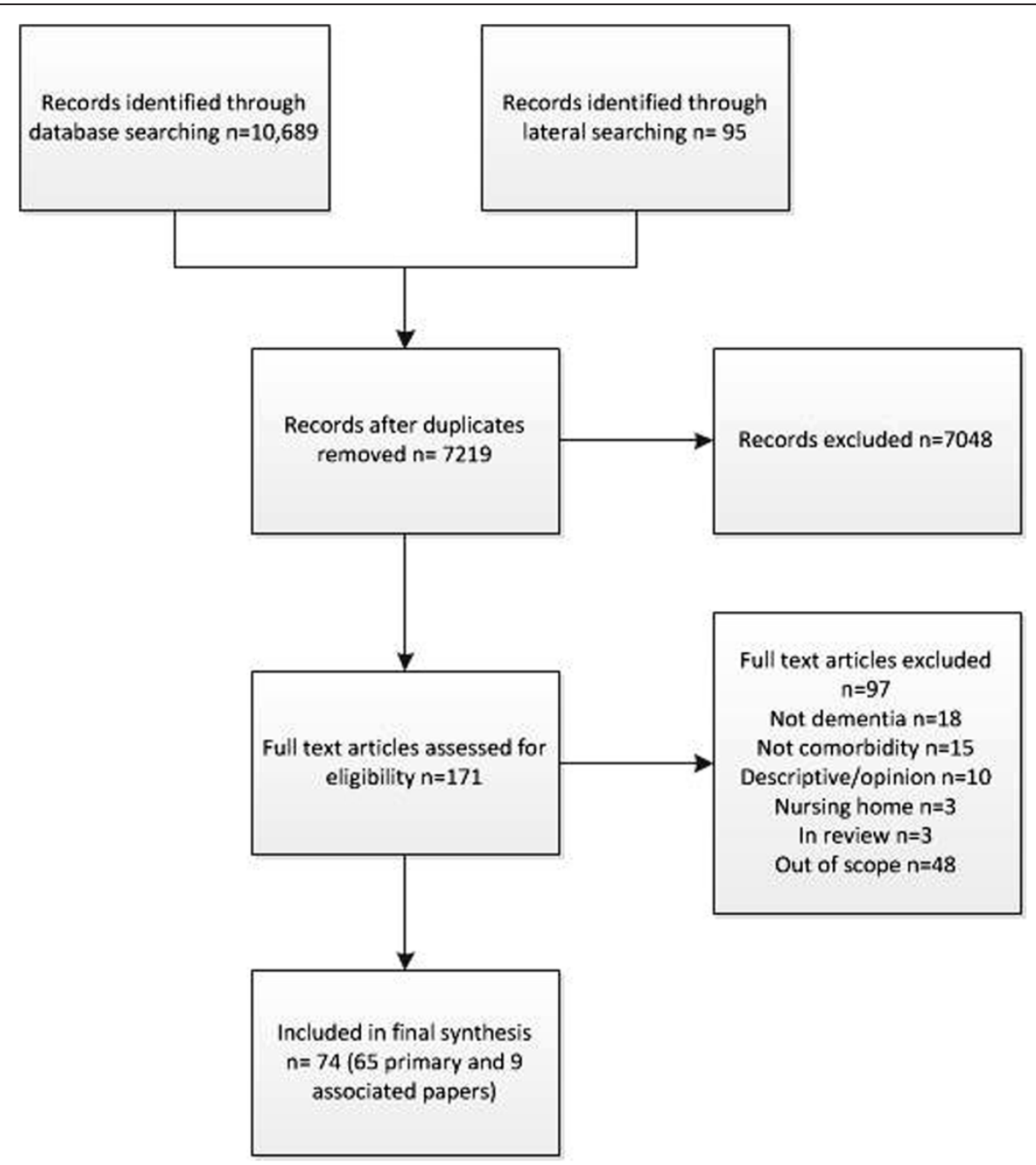

Figure 1 Flow chart study selection process.

- Survey number $=3$

- Review/scoping number $=8$

- Other number $=5$

Areas covered in study ${ }^{b}$

- Prevalence number $=28$

- Service organisation and delivery number $=16$

- Views and experiences number $=12$

- Quality of care number $=21$

Setting

- Hospital/outpt clinic number $=30$

- Community number $=12$

- Primary care number $=7$

- Mixed community/residential care number $=5$

- Population based sample number $=8$

Type of participants

Type of cognitive impairment

- Dementia number $=40$
- Cognitive impairment (including dementia and delirium) number $=8$

- Mixed population including people with dementia and MCI number $=10$

- $\mathrm{MCI}=9$

Age

- Range 43 to 102 but majority over 70

- Of 38 studies that gave a mean age - majority had mean age in $70 \mathrm{~s}$

Ethnicity

- Not specified number $=36$

- White (or majority white) number $=14$

- Mixed number $=3$

- Mixed but majority black number $=2$

- NA (for example, review) number $=10$

Comorbidities included in studies ${ }^{\mathrm{b}}$

- Diabetes number $=15$ 
- Stroke number $=3$

- Visual impairment number $=14$

- Other comorbidities number $=7$ (for example, cancer, MI)

- General comorbidity number $=12$

- More than one comorbidity (but includes one of our target conditions) number $=14$

Type of dementia

- Alzheimers number $=8$

- Mixture of different types number $=4$

- Not reported in rest

\section{Prevalence}

Our main aim was to look at the prevalence of comorbidity (in particular stroke, diabetes and visual impairment) in people with dementia. Thirteen studies provided data about the prevalence of comorbidities in people with dementia $[2,5,26,46,55,56,58,64,65,75,80-82]$ and two the prevalence of comorbidities in people with mild cognitive impairment (MCI) [36,72] (see Table 2). The representativeness of the samples varied. Four studies included population based samples [36,55,56,72], six recruited populations from primary care databases $[2,5,26,58,64,82]$ and five used samples from hospitals or out-patient clinics [46,65,75,80,81] [see Additional file 2]. Data were collected from medical records in six studies $[26,46,64,75,80,82]$, from clinical examination or interviews in six $[2,36,55,56,65,72]$ and from a mixture of medical records and clinical examination in three $[5,58,81]$. The presence of dementia and comorbid medical conditions was assessed using a variety of measures [see Additional file 3].

We also included a further eight studies that reported the prevalence of dementia in people with one of our three target comorbidities [30,38,39,47,66,78,79,83] (see Table 3). Three studies included samples from outpatient clinics $[38,78,79]$, one data from an RCT in primary care [47], two research administration or health claims databases in the USA [39] and Australia [83], one from a stroke register in Canada [66] and one a population derived community-based sample in Australia [30]. Three collected data from medical or database records $[39,66,83]$ and the rest from face to face interviews or clinical examinations.

\section{Prevalence of target comorbidities in people with dementia Diabetes}

Twelve studies reported the prevalence of diabetes in populations of people with dementia $[5,26,46,55,56,58,64,65,80,81]$ or MCI [36,72]. Prevalence rates varied from $6 \%$ to $39 \%$. The two largest studies which both involved participants from national primary care data sets in the UK, one from Scotland [26] and one from the UK (primarily England) [64], reported similar prevalence rates of 13\% [26] (personal communication B Guthrie) and 14\% [64]. Five studies compared rates of diabetes in those with and without dementia. Of those, three studies with samples recruited from primary care databases, two from the USA and one from the UK, found similar rates between groups $[5,58,64]$ and a study in hospital inpatients in Switzerland found no significant differences in rates of diabetes mellitus between those with and without dementia [81]. In contrast, a study of hospital in-patients in the UK found significantly fewer people with dementia diagnosed with type-2 dementia than controls without dementia [46].

\section{Stroke}

Nine studies reported the prevalence of stroke in people with dementia $[5,26,46,55,56,58,64,80,81]$ and two in people with cognitive impairment $[36,72]$. Prevalence rates varied from $3 \%$ in hospitalised older people in the UK [46] to $34 \%$ in a sample of urban and rural community dwelling people with cognitive impairment in the USA [36]. Two studies used records from large primary care databases in the UK, one reported that rates of stroke in people with dementia were 19\% [26] and the other that rates of cerebrovascular disease (including stroke) were 29\% [64]. Five studies compared rates of stroke in people with and without dementia. Three found no significant difference in the prevalence of stroke $[5,46,81]$, but one study of hospital inpatients found that stroke was more common in people with dementia [56] and a primary care based study in the UK found a greater prevalence of cerebrovascular disease in people with dementia [64].

\section{Visual impairment}

Four studies reported the prevalence of some form of visual impairment in people with dementia, including all eye diseases [80], glaucoma $[46,55]$ and cataracts $[55,82]$. Differences in the populations studied and the way cases were identified make comparisons across studies difficult. Two studies compared rates of glaucoma in people with dementia and those without; prevalence in people with dementia was lower in a population sample in Finland [55] but not different in hospital inpatients in a retrospective case control study in the UK [46]. Two studies compared rates of cataracts. A large primary care cohort study in the UK found a lower incidence rate for cataracts in people with $\mathrm{AD}$ than controls [82] but a smaller populationbased study in Finland reported no difference in the rates of cataracts [55].

\section{Prevalence of dementia in people with stroke, diabetes and visual impairment}

Five studies looked at the prevalence of dementia or cognitive impairment in populations of people with diabetes. In a large population-based study in the USA, 13\% of people with diabetes had dementia or cognitive impairment [39] compared with $23 \%$ in a sample recruited through primary 
Table 2 Prevalence of diabetes, visual impairment and stroke in people with dementia

\begin{tabular}{|c|c|c|c|c|c|c|c|c|c|c|c|}
\hline $\begin{array}{l}\text { Study and } \\
\text { country }\end{array}$ & Study type & Dementia/CI & $\begin{array}{l}\text { Control/ } \\
\text { comparison }\end{array}$ & Eligibility criteria & Recruited from & $\begin{array}{l}\text { Number } \\
\text { whole sample }\end{array}$ & $\begin{array}{l}\text { Number } \\
\text { dementia/Cl }\end{array}$ & $\begin{array}{l}\text { Diabetes } \\
(\%)\end{array}$ & $\begin{array}{l}\text { Stroke } \\
(\%)\end{array}$ & $\begin{array}{l}\text { VI } \\
(\%)\end{array}$ & Notes \\
\hline $\begin{array}{l}\text { Barnett [26] } \\
\text { UK (Scotland) }\end{array}$ & Cross-sectional & Dementia & NA & $\begin{array}{l}\text { Alive, permanently } \\
\text { registered with a } \\
\text { participating practice }\end{array}$ & $\begin{array}{l}\text { Primary care - } \\
\text { national dataset }\end{array}$ & 1751841 & 11139 & 13.3 & 18.8 & 3.8 & $\begin{array}{l}\mathrm{VI} \text { is blindness/low } \\
\text { vision }\end{array}$ \\
\hline $\begin{array}{l}\text { Doraiswamy } \\
\text { [2] }\end{array}$ & Cross-sectional & Dementia & NA & $\begin{array}{l}\text { Diagnosis of Alzheimer's } \\
\text { disease, } 50 \text { or over }\end{array}$ & $\begin{array}{l}\text { Community health } \\
\text { care sites }\end{array}$ & 679 & 679 & - & - & - & $\begin{array}{l}61 \% \text { had three or } \\
\text { more comorbidities, } \\
30 \% \text { had vascular or } \\
\text { heart disease. Sample } \\
\text { included mixture of } \\
\text { community dwelling } \\
\text { and long-term care }\end{array}$ \\
\hline Feil [36] USA & $\begin{array}{l}\text { Longitudinal } \\
\text { cross sectional }\end{array}$ & $\mathrm{Cl}$ & $\mathrm{No} C l$ & $\begin{array}{l}\text { Geographically defined, } \\
65 \text { and over }\end{array}$ & $\begin{array}{l}\text { Population derived } \\
\text { sample }\end{array}$ & 7482 & 1774 & 26 & 34 & - & \\
\hline Heun [46] UK & $\begin{array}{l}\text { Retrospective } \\
\text { case control }\end{array}$ & Dementia & No dementia & $\begin{array}{l}\text { Diagnosis of AD, } 70+\text {, } \\
\text { in-patient care for at } \\
\text { least } 24 \text { hours }\end{array}$ & Hospital in-patients & 72878 & 634 & 6 & 3 & 1 & $\begin{array}{l}\text { VI is glaucoma. Diagnosis } \\
\text { of diabetes less common } \\
\text { in those with AD than } \\
\text { controls RR } 0.7(95 \% \text { Cl } \\
0.5 \text { to } 0.9) \text {. No significant } \\
\text { difference in prevalence } \\
\text { of ischemic stroke RR } \\
1.395 \% \text { Cl } 0.9 \text { to } 2.0 \text {, or } \\
\text { glaucoma RR } 2.0 \text { (1.0 } \\
\text { to 4.3) }\end{array}$ \\
\hline Jara [82] UK & $\begin{array}{l}\text { Retrospective } \\
\text { cohort }\end{array}$ & Dementia & No dementia & $\begin{array}{l}64 \text { and over, at least } 24 \\
\text { months continuous } \\
\text { enrolment, no cataract } \\
\text { diagnosis at baseline }\end{array}$ & $\begin{array}{l}\text { Primary care - } \\
\text { national dataset }\end{array}$ & 650325 & 8124 & - & - & - & $\begin{array}{l}\text { Lower rate of any } \\
\text { cataract in } \mathrm{AD} \text { group } \\
\text { compared to controls } \\
\text { HR } 0.52(95 \% \mathrm{Cl} 0.47 \\
\text { to } 0.58)\end{array}$ \\
\hline $\begin{array}{l}\text { Löppönen } \\
\text { [55] Finland }\end{array}$ & Cross-sectional & Dementia & NA & $\begin{array}{l}\text { Geographically defined, } \\
65 \text { and over }\end{array}$ & Population based & 1260 & 112 & 16 & 24 & 29 & $\begin{array}{l}\text { PWD less likely to be } \\
\text { diagnosed with } \\
\text { glaucoma OR 0.36; } 95 \% \\
\text { Cl } 0.15 \text { to } 0.86) \text {, no } \\
\text { difference in rates of } \\
\text { cataract } p=0.287\end{array}$ \\
\hline $\begin{array}{l}\text { Lyketsos } \\
\text { [56] USA }\end{array}$ & Case-control & Dementia/Cl & No dementia/Cl & $\begin{array}{l}\text { Geographically defined, } \\
65 \text { and over }\end{array}$ & Population based & 695 & 374 & 20 & 16 & - & $\begin{array}{l}\text { Stroke more common } \\
\text { in people with } \\
\text { dementia } p<0.001\end{array}$ \\
\hline $\begin{array}{l}\text { McCormick } \\
\text { [58] USA }\end{array}$ & Case-control & Dementia/Cl & No dementia/Cl & $\begin{array}{l}\text { Aged } 60 \text { and over, } \\
\text { members of } \mathrm{HMO} \\
\text { geographically defined }\end{array}$ & $\begin{array}{l}\text { Population derived } \\
\text { (from HMO database) }\end{array}$ & 154 & 154 & 6 & $3^{a}$ & 10 & $\begin{array}{l}\text { Visual problems less } \\
\text { common in PWD ( } 10 \% \\
\text { versus 24\%) }\end{array}$ \\
\hline
\end{tabular}


Table 2 Prevalence of diabetes, visual impairment and stroke in people with dementia (Continued)

\begin{tabular}{|c|c|c|c|c|c|c|c|c|c|c|c|}
\hline Rait [64] UK & Cohort & Dementia & No dementia & $\begin{array}{l}60 \text { and over with first } \\
\text { code for dementia } \\
\text { during study period, } \\
\text { at least six months data }\end{array}$ & $\begin{array}{l}\text { Primary care - } \\
\text { national dataset }\end{array}$ & 135174 & 22529 & 14 & $29^{a}$ & - & $\begin{array}{l}\text { No difference in } \\
\text { prevalence of diabetes } \\
\text { (13.9\% versus } 14.5 \%) \\
\text { but cerebrovascular } \\
\text { disease more common } \\
\text { in people with dementia } \\
\text { (29.3\% versus } 13.3 \%)\end{array}$ \\
\hline $\begin{array}{l}\text { Sakurai [65] } \\
\text { Japan }\end{array}$ & $\begin{array}{l}\text { Cross } \\
\text { sectional }\end{array}$ & Dementia & NA & Dementia or $\mathrm{MCl}$ & Memory clinic & 160 & 160 & 19 & - & - & Dementia and $\mathrm{Cl}$ \\
\hline $\begin{array}{l}\text { Schubert [5] } \\
\text { USA }\end{array}$ & Cross-sectional & Dementia & No dementia & $\begin{array}{l}65 \text { and older, seen primary } \\
\text { care physician within two } \\
\text { years. Excluded nursing } \\
\text { home residents, non-English } \\
\text { speaking }\end{array}$ & Primary care & 3013 & 107 & 39 & 10 & - & $\begin{array}{l}\text { No significant } \\
\text { difference in prevalence } \\
\text { of } \mathrm{DM}(P=0.19 \text { ) or stroke } \\
\text { ( } P=0.89) \text { between those } \\
\text { with and without } \\
\text { dementia }\end{array}$ \\
\hline $\begin{array}{l}\text { Stephan [72] } \\
\text { UK }\end{array}$ & Cross-sectional & $\mathrm{MCl}$ & $\mathrm{No} \mathrm{MCl}$ & 65 and over & Population based & 13004 & 1486 & 7 & 19 & - & \\
\hline $\begin{array}{l}\text { Uhlmann[75] } \\
\text { USA }\end{array}$ & Case control & Dementia & No dementia & $\begin{array}{l}65 \text { and over, English } \\
\text { speaking, eighth-grade } \\
\text { or higher education, } \\
\text { ability to complete } \\
\text { audiometric evaluation }\end{array}$ & $\begin{array}{l}\text { Adult medicine } \\
\text { clinic }\end{array}$ & 174 & 87 & $\begin{array}{l}\text { not } \\
\text { given }\end{array}$ & $\begin{array}{l}\text { not } \\
\text { given }\end{array}$ & - & $\begin{array}{l}\text { Prevalence of } \mathrm{VI} \\
\text { significantly higher in } \\
\text { cases than controls } \\
\text { (OR } 295 \% \mathrm{Cl} 1.2-3.4 \text { ). }\end{array}$ \\
\hline $\begin{array}{l}\text { Zamrini [80] } \\
\text { USA }\end{array}$ & Case control & Dementia & NA & $\begin{array}{l}\text { Probable AD, black or } \\
\text { white (white participants } \\
\text { matched non randomly } \\
\text { to black participants) }\end{array}$ & $\begin{array}{l}\text { Memory clinic } \\
\text { database }\end{array}$ & 334 & 334 & 18 & 9 & 10 & $\begin{array}{l}\text { Includes all eye } \\
\text { diseases }\end{array}$ \\
\hline $\begin{array}{l}\text { Zekry [81] } \\
\text { Switzerland }\end{array}$ & Cohort & Dementia & No dementia & $\begin{array}{l}75 \text { and over. Excluded: } \\
\text { terminal illness, disorders } \\
\text { interfering with psychometric } \\
\text { assessment }\end{array}$ & Hospital in-patients & 349 & 188 & 19 & 22 & - & $\mathrm{MCl}+$ dementia \\
\hline
\end{tabular}




\begin{tabular}{|c|c|c|c|c|c|c|c|}
\hline Study and country & Type of study & Type of population & Control/comparison & Eligibility criteria & Recruited from & $\begin{array}{l}\text { Number whole } \\
\text { sample }\end{array}$ & Number dementia/Cl \\
\hline Bruce [30] Australia & $\begin{array}{l}\text { Longitudinal } \\
\text { cross sectional }\end{array}$ & DM & NA & $\begin{array}{l}\text { Defined by post-code, } 70 \text { years } \\
\text { or older, diabetes }\end{array}$ & $\begin{array}{l}\text { Patients living in catchment } \\
\text { area of hospital ( } 63 \% \text { of eligible } \\
\text { patients recruited) }\end{array}$ & 223 & $34(15.3 \%)$ \\
\hline Feil [38] USA & $\begin{array}{l}\text { Longitudinal } \\
\text { cross-sectional }\end{array}$ & DM & NA & $\begin{array}{l}\text { Diagnosis of type } 2 \text { diabetes, } \\
60 \text { years or older }\end{array}$ & Geriatric clinic & 51 & $23(45 \% \mathrm{Cl})$ \\
\hline Feil [39] USA & Cross-sectional & DM & NA & $\begin{array}{l}\text { Veterans aged } 65 \text { and older } \\
\text { with diabetes mellitus }\end{array}$ & $\begin{array}{l}\text { Research administration database } \\
\text { (Veterans Health Administration) }\end{array}$ & 497000 & 65107 (13\% dementia/CI) \\
\hline Hewitt [47] UK & Questionnaire & DM & NA & $\begin{array}{l}\text { Type } 2 \text { diabetes, aged } 75 \text { and } \\
\text { older, not resident in nursing } \\
\text { homes }\end{array}$ & Data from RCT in Primary Care & 1047 & 235 (22.5\% dementia/Cl) \\
\hline Zhang [83] Australia & $\begin{array}{l}\text { Retrospective } \\
\text { cohort study }\end{array}$ & DM & NA & $\begin{array}{l}\text { Veterans, } 65 \text { and older, received } \\
\text { prescription for diabetes in } \\
\text { previous six months }\end{array}$ & Health claims database & 17095 & $4.4 \%$ \\
\hline Saposnik [66] Canada & $\begin{array}{l}\text { Retrospective } \\
\text { cohort study }\end{array}$ & Stroke and dementia & Stroke no dementia & $\begin{array}{l}18 \text { years and older, first } \\
\text { ischemic stroke }\end{array}$ & $\begin{array}{l}\text { Stroke register (included patients } \\
\text { admitted to } 12 \text { regional stroke } \\
\text { centres in Ontario) }\end{array}$ & 10658 & $966(9.1 \%)$ \\
\hline Whitson [78] USA & Cross-sectional & VI (macular disease) & NA & $\begin{array}{l}65 \text { and older, macular disease } \\
\text { diagnoses }\end{array}$ & Low Vision Rehabilitation clinic & 101 & $19(19 \%)$ \\
\hline Yochim [79] & Case series & VI (glaucoma) & NA & $\begin{array}{l}50 \text { and older, diagnosis of } \\
\text { glaucoma }\end{array}$ & Glaucoma clinic & 41 & $44 \%(\mathrm{MCl})$ \\
\hline
\end{tabular}

$\mathrm{Cl}$, Cognitive impairment; $\mathrm{DM}$, diabetes mellitus $\mathrm{MCl}$, mild cognitive impairment; $\mathrm{RCT}$, randomised controlled trial; $\mathrm{Vl}$, visual impairment. 
care in the UK [47]. Two studies reported the prevalence of dementia in people with visual impairment recruited via eye clinics. In one [78] 19\% of people with macular disease had dementia and in the other [79] 20\% of people with glaucoma had memory impairment and $22 \%$ impaired executive functioning. One study looked at the prevalence of dementia amongst people who had had a stroke. Of more than 10,000 people on a stroke register $9 \%$ were reported to have dementia.

\section{Quality of care}

We categorised 23 studies as relating to quality of care in some way, 11 of which compared access to treatment or receipt of services in groups with and without dementia. Ten of the 11 studies found some evidence that people with dementia were less likely to receive the same quality of care or access to services compared to those without dementia. For example, studies found that people with dementia were less likely to receive monitoring for diabetes related problems [32,74] and had reduced access to treatment, such as intravenous thrombolysis for stroke [66], surgery for cataracts [45], treatment for age-related macular degeneration (AMD) [11,33] or services for diabetes $[77,83]$. More details can be seen in Table 4. A German study reported that older people with a greater number of comorbidities were less likely to receive cholinesterase inhibitors for dementia [48] and a Canadian study found evidence that pain is undertreated in people with dementia and arthritis [25].

In addition, there was evidence that having dementia or cognitive impairment impacts on a person's ability to undertake self-care management. For example, people with dementia and diabetes had problems understanding their condition, managing medication and monitoring their blood glucose [13,29,37,38,47].

\section{Views and experiences}

We included 11 studies looking at views and experiences of people with dementia, their family carers and health care professionals. Six were qualitative [27,37,54,62,70], one was a mixed study including a review and qualitative study [42], two were reviews [28,34] and two were questionnaire studies $[29,47]$. Three studies focused on people with dementia and diabetes $[29,37,47]$, two visual impairment [28,54], one deafness [24], one cancer [27] and four on the needs of people with dementia in general hospitals $[34,42,62,70]$.

Literature on the experiences of older people with dementia in acute general hospitals has highlighted shortcomings in the care provided, attitudes and training of staff, the physical environment and problems with care cultures $[34,42,62]$. Poor communication is a major barrier to the provision of good care for people with dementia and a comorbid health condition $[34,42,54]$. Practitioners reported that they found it difficult to communicate with people with dementia and communication difficulties are compounded when they have additional comorbidities which make communication difficult, such as hearing loss or sight loss $[24,27,54]$. There were also problems with communication between different professionals and specialist teams with a lack of coordinated working between practitioners in different specialities [54]. A lack of appropriate knowledge and training was also a major barrier, with those working in acute care hospitals [42], palliative care [27] and diabetes [39] lacking knowledge about dementia. Conversely, those in dementia services may lack awareness about how to support people with dementia and visual impairment $[54,88]$.

A qualitative study involving the views of 21 caregivers of people with dementia and type 2 diabetes found that behavioural and psychological symptoms of dementia disrupted diabetes care. In addition, carers felt that they received inadequate support in planning their relatives care, that their contribution to managing their relatives care was not always recognised and that they were often excluded from decision making [37].

\section{Service organisation and delivery Guidelines and care pathways}

Guidance on the care of older people with diabetes highlights the need to balance the benefits of diabetes treatment while minimising the risk in people with dementia [49] as this group may be at increased risk of hypoglycaemia $[49,68]$ and guidance from the College of Optometrists states that when examining patients with dementia optometrists have a duty to carry out whatever tests are necessary to determine the patients' need for vision care [31]. However, most guidelines are condition specific and generally fail to take into account multimorbidity or the needs of people with dementia $[38,47,72,77,84,88]$.

A recent review identified 16 guidelines/position statements or standards (from the UK, USA and Australia) for the care of people with dementia but these generally focused on standards for providing optimal care for older people with cognitive impairment in acute hospitals or specific issues, such as hydration, nutrition or wandering [23]. They did not cover issues relating to the care of people with dementia and specific medical conditions (such as diabetes). Moreover, most models of practice for work with people with dementia do not mention visual impairment [88].

\section{Models of care for older people with cognitive impairment} A number of initiatives have been developed to improve the care of older people with dementia in acute hospitals, including liaison psychiatric services [50,73] or specialist units that combine medical and mental health care for older people $[41,44]$. Much of the work in this area is 
Table 4 Impact of dementia and medical comorbidities on quality of care and access to treatment

\begin{tabular}{|c|c|c|c|c|c|c|c|}
\hline Study ID & Country & Comorbidity & Study type & Number of participants & $\begin{array}{l}\text { Aspect of } \\
\text { quality of care }\end{array}$ & $\begin{array}{l}\text { Evidence that } \\
\text { care is different? }\end{array}$ & Reported differences in care/treatment \\
\hline Connolly [92] & UK & DM, Stroke & Cross sectional & $\begin{array}{l}700 \text { PWD (compared to people without } \\
\text { dementia on QOF register) }\end{array}$ & $\begin{array}{l}\text { Monitoring and } \\
\text { treatment }\end{array}$ & Yes & $\begin{array}{l}\text { PWD -significantly lower on } 73 \% \text { of QOF indicators; } \\
\text { including peripheral pulses check, neuropathy } \\
\text { testing, cholesterol measures for stroke. }\end{array}$ \\
\hline Curtis [33] & USA & VI (AMD) & $\begin{array}{l}\text { Retrospective } \\
\text { cohort }\end{array}$ & 284380 & Treatment & Yes & $\begin{array}{l}\text { PWD significantly less likely to receive anti-VEGF RR } \\
0.88 \text { ( } 95 \% \mathrm{Cl} 0.88 \text { to } 0.89)\end{array}$ \\
\hline Guijarro [45] & Spain & Vl, general & Cohort & 40482 & Treatment & Yes & $\begin{array}{l}\text { PWD had some procedures less frequently than } \\
\text { those without dementia. For example,cataract } \\
\text { surgery }(P<0.001) \text {, hernia repair, orthopaedic } \\
\text { surgery }\end{array}$ \\
\hline Keenan [11] & UK & VI (AMD) & Cohort & 65894 (AMD cohort, 168092 dementia cohort) & Treatment & Yes & $\begin{array}{l}\text { PWD significant decrease in likelihood of hospital } \\
\text { admission for AMD } P<0.001\end{array}$ \\
\hline Löppönen [55] & Finland & Vl, general & $\begin{array}{l}\text { Cross sectional } \\
\text { (survey) }\end{array}$ & 1260 older people (112 PWD) & $\begin{array}{l}\text { Diagnosis and } \\
\text { treatment }\end{array}$ & Yes & $\begin{array}{l}\text { PWD -more undiagnosed diseases compared to those } \\
\text { without dementia }(P=0.041) \text {, less likely to be } \\
\text { diagnosed with glaucoma }(P=0.022)\end{array}$ \\
\hline Müther [60] & Germany & $\begin{array}{l}\text { DM, } \\
\text { hypertension }\end{array}$ & $\begin{array}{l}\text { Retrospective } \\
\text { matched control }\end{array}$ & 216 PWD, 216 matched controls & Treatment & No & $\begin{array}{l}\text { No significant differences in treatment for those } \\
\text { with and without dementia. PWD more likely not to } \\
\text { receive medication for hypertension or be treated } \\
\text { with low-priced medications (not significant) }\end{array}$ \\
\hline \multirow[t]{2}{*}{ Saposnik [66] } & \multirow[t]{2}{*}{ Canada } & \multirow[t]{2}{*}{ Stroke } & \multirow[t]{2}{*}{ Cohort } & 877 with pre-existing dementia & \multirow[t]{2}{*}{ Treatment } & \multirow[t]{2}{*}{ Yes } & \multirow{2}{*}{$\begin{array}{l}\text { Patients with pre-existing dementia less likely to receive } \\
\text { intravenous thrombolysis. }\end{array}$} \\
\hline & & & & 877 controls (no pre-existing dementia) & & & \\
\hline Sloan [69] & USA & Acute MI & Cross sectional & $\begin{array}{l}5851 \text { admitted for AMI with dementia, } 123241 \\
\text { admitted for AMI without dementia }\end{array}$ & Treatment & Yes & $\begin{array}{l}\text { PWD less likely to have a range of invasive } \\
\text { procedures compared to those without a history of } \\
\text { dementia }\end{array}$ \\
\hline Thorpe [74] & USA & $\mathrm{DM}, \mathrm{VI}$ & Cohort & 288805 (44717 PWD) & Monitoring & Yes & $\begin{array}{l}\text { PWD less likely to receive } \mathrm{HbA} 1 \mathrm{C} \text { tests ( } 73 \% \text { versus } \\
81 \%), \mathrm{LDL}-\mathrm{C} \text { tests }(61 \% \text { versus } 79 \%) \text {, and eye } \\
\text { examinations ( } 52 \% \text { versus } 63 \%) \text {. }\end{array}$ \\
\hline Vitry [77] & Australia & DM & Cohort & $\begin{array}{l}20134 \text { veterans with diabetes (includes people } \\
\text { with dementia/Cl but numbers not clear) }\end{array}$ & Treatment & Yes & $\begin{array}{l}\text { Presence of dementia associated with decreased } \\
\text { likelihood of treatment intensification (for example, } \\
\text { addition of antidiabetic medicine or switch to } \\
\text { insulin/different medication) }\end{array}$ \\
\hline Zhang [83] & Australia & $\mathrm{DM}, \mathrm{Vl}$ & Cohort & $\begin{array}{l}17095 \text { veterans with and without diabetes } \\
(4.4 \% \text { on dementia medication) }\end{array}$ & $\begin{array}{l}\text { Treatment, } \\
\text { access to } \\
\text { services }\end{array}$ & Yes & $\begin{array}{l}\text { Patients receiving medications prescribed for } \\
\text { dementia less likely to use diabetic and optometry/ } \\
\text { ophthalmology services. }\end{array}$ \\
\hline
\end{tabular}

AMD, age-related macular degeneration; AMI, acute myocardial infarction; Cl, cognitive impairment; DM, diabetes mellitus; HbA1c, glycosylated hemoglobin; LDL-C, low-density lipoprotein cholesterol PWD, people with dementia; QOF, quality of life; VEGF, vascular endothelial growth factor; VI, visual impairment. 
descriptive [41] although a specialist medical and mental health unit for people with dementia has recently been evaluated in an RCT [44]. They found no difference between the specialist unit and standard care on general medical wards for their primary outcome (days spent at home) but there were significant differences in process items in favour of the intervention, and family carers were more satisfied [44]. However, the study excluded patients with clinical needs for specialist services, such as surgery or stroke units.

A scoping review of interventions for cognitively impaired older people in emergency departments found no evaluations of organisational or system level interventions and little evidence of appropriate interventions [61]. We found no evaluations of interventions aimed specifically at our three target comorbidities, although a retrospective analysis of stroke patients suggested that cognitively impaired patients benefit from admission to an acute rehabilitation stroke unit [63].

\section{Discussion}

We included 54 primary studies, eight reviews and two guidelines that addressed issues around dementia and comorbidity. We found evidence of a lack of continuity in health care systems and structures for people with dementia and comorbidity, with little integration or communication between different teams and specialities [54]. Moreover, many models of care are focused on single diseases and do not take into account the needs of those with multimorbidity $[26,84]$ or of their family carers. We found a number of studies reporting prevalence for our three target comorbidities. Whilst heterogeneity in the populations and differences in the way that conditions were ascertained make comparisons across studies difficult the data do suggest that rates of diabetes in people with dementia may be between 13 and 20 percent and of stroke between 16 and 29 percent.

We undertook a scoping review rather than a systematic review. A limitation of such an approach is that the review does not include an assessment of the quality of the included studies or evaluate the effectiveness of interventions. However, evaluative research in this area is limited and our aim was to examine the extent, range and nature of research activity around patient and carer need, health care provision and service organisation for people with dementia and comorbidity. Moreover, whilst we did not undertake formal quality assessment we did extract methodological information on study populations and data collection methods that aided in the interpretation of the evidence. We set out to include a representative rather than exhaustive range of literature and it is possible that we have missed relevant studies or guidelines. However, our search strategy was guided by systematic review methodology and we employed extensive database and lateral searches. We are confident, therefore, that this scoping review provides a comprehensive summary of current evidence relating to dementia and comorbidity for people living in the community, particularly in relation to diabetes, stroke and visual impairment. We did, however, exclude studies in care homes where there are likely to be considerable levels of dementia and comorbidity. Moreover, the majority of our studies focus on single comorbidities and the review does not cover the presence of multiple conditions. The support that people with dementia and multiple health conditions need may be different than those with less complex needs. Further studies are needed to understand the complexity within multiple comorbidities.

To our knowledge, this is the first review of research and practice on co-morbidity in dementia. Most research on multimorbidity has been concerned with its effect on physical functioning and its measurement, with little research investigating the effect on processes of care or what constitutes 'best care' for these patients [14]. Moreover, qualitative research on dementia has tended to focus on the experience of living with dementia as a single disease [15]. This review sets out current research and knowledge about the impact of comorbidities on people diagnosed with dementia and what is known about their experiences of health care.

This review suggests that significant numbers of people with dementia have a comorbid health condition, such as diabetes or stroke. This has serious implications for the way that specialist services for conditions such as diabetes are delivered for people with dementia. Despite these high levels of comorbidity in people with dementia there was evidence that they did not have the same access to treatment and monitoring for conditions such as visual impairment and diabetes as those with similar comorbidities but without dementia. There may be a variety of factors that contribute to this finding. For example, people with dementia may be less likely to attend regular appointments or to notice or report relevant symptoms and they may be more reliant on carers to manage and facilitate appointments [11]. It is also possible that clinicians may be more reluctant to investigate and treat patients with dementia either because of the difficulties involved in securing patient cooperation or because treatments are considered inappropriate for older patients with multimorbidity. In addition, if the dementia is symptomatic (such as the behavioural and psychological symptoms associated with dementia) then dementia may become clinically dominant and detract from the management of conditions such as diabetes mellitus [93,94].

Much of the available literature relates to the prevalence of comorbidities in people with dementia or issues around quality of care. There is less evidence relating to service organisation and delivery, patient and carer preferences or the decision making processes of clinicians involved in their care. Whilst there is literature relating to 
models of care for older people with cognitive impairment, this is focused on in-patient care for patients who would otherwise be admitted to a general medical ward and does not provide guidance on the management of specific conditions (such as diabetes or stroke) in people with dementia. In addition there is little guidance on the care of people with dementia and long-term conditions living in the community. Family caregivers of people who have dementia and other health conditions face great challenges in managing both conditions and dealing with the impact of accompanying behavioural and psychological symptoms of dementia on care routines [37]. Despite this, little is known about how family carers can best be supported, or how health care services should adapt to address the particular needs of this population.

\section{Recommendations for research}

The review highlights significant gaps in the evidence. There is currently a lack of research on the experiences of patients and their family carers on living with dementia and comorbid conditions. Even less is known about healthcare providers experiences of managing people living with dementia and comorbid health conditions and how the presence of dementia influences the care they receive for their comorbidity. These are areas that are currently being explored in an NIHR study on dementia and comorbidity [21]. In addition, there is a need for more detailed epidemiological work on the prevalence of comorbidities in people with dementia and the appropriateness of treatment and referral for this group. People with dementia should be included in debate about the management of comorbidities in older populations, and there needs to be greater consideration given to including them in studies and trials that focus on age-related healthcare issues. Equally, dementia-specific studies need to consider the impact of comorbidities on the experience of living and dying with dementia.

\section{Conclusions}

The prevalence of comorbid conditions in people with dementia is high. Whilst current evidence suggests that people with dementia may have poorer access to services the reasons for this are not clear. There is a need for more research looking at the ways in which having dementia impacts on clinical care for other conditions, how process of care and different services can adapt to the needs of people with dementia and comorbidity, and what interventions might improve access to services and the physical health of people with dementia. Clinical guidance should consider the particular needs of those with dementia and comorbid health conditions.

\section{Endnotes}

${ }^{a}$ All numbers refer to the numbers of studies not individual participants.

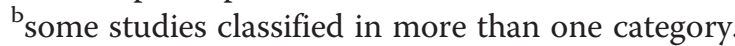

\section{Additional files}

Additional file 1: Table of included studies.

Additional file 2: Prevalence studies - information on study populations, recruitment and participation.

Additional file 3: Prevalence studies - information on methods of data collection.

\section{Abbreviations}

AMD: age-related macular degeneration; AMED: Allied and Complementary Medicine Database; CENTRAL: Cochrane Central Register of Controlled Trials; CDSR: Cochrane Database of Systematic Reviews; Cl: cognitive impairment; DARE: Database of Abstracts of Reviews of Effectiveness; HTA: health technology assessment; MCl: mild cognitive impairment; $\mathrm{RCT}$ : randomised controlled trial; Vl: visual impairment.

\section{Competing interests}

The authors declare that they have no competing interests.

\section{Authors' contributions}

FB wrote the protocol, undertook data extraction, quality assessment and analysis and wrote the paper. AMB undertook data extraction, quality assessment and analysis and helped to write the paper. CG participated in study design, interpretation of the results and helped to revise the paper. GR participated in study design, interpretation of the results and helped to revise the paper. CB participated in study design, interpretation of the results and critical review of the paper. LR participated in study design, interpretation of the results and critical review of the paper. SN participated in the design of the study and advised on interpretation of the prevalence data. JS participated in study design, interpretation of the results and critical review of the paper. FB confirms that the manuscript is an honest, accurate, and transparent account of the study being reported, that no important aspects of the study have been omitted, and that any discrepancies from the review as planned have been explained. All authors read and approved the final manuscript.

\section{Acknowledgements}

We would like to thank Reinhard Wentz who helped design and run the database searches and Professor Bruce Guthrie for providing us with additional unpublished data.

\section{Funding}

This article presents independent research commissioned by the National Institute for Health Research (NIHR) under HS \& DR (Grant Reference Number $11 / 1017 / 07)$. The views expressed in this paper are those of the authors and not necessarily those of the NHS, the NIHR or the Department of Health. The sponsor of the study had no role in study design, data analysis, data interpretation or writing of the report.

\section{Author details}

${ }^{1}$ Centre for Research in Primary and Community Care, University of Hertfordshire, College Lane, Hatfield, Hertfordshire AL10 9AB, UK. ${ }^{2}$ Research Department of Primary Care and Population Health, UCL Medical School (Royal Free Campus), Rowland Hill Street, London NW3 2PF, UK. ${ }^{3}$ Department of Psychology, Institute of Psychiatry, King's College London, Guy's Hospital Campus, London SE1 9RT, UK. Institute for Health and Society, Newcastle University, Newcastle upon Tyne NE2 4AX, UK. 5South Essex Partnership Trust, Luton, UK. ${ }^{6}$ Department of Public Health and Primary Care, University of Cambridge, Cambridge CB1 8RN, UK.

Received: 23 July 2014 Accepted: 26 September 2014

Published online: 31 October 2014 
References

1. Prince M, Jackson J: World alzheimer report 2009. In Alzheimer's Disease International. London: Alzheimer's Disease International; 2009. Available at: http://www.alz.co.uk/research/files/WorldAlzheimerReport.pdf. Accessed 18 September 2012.

2. Doraiswamy PM, Leon J, Cummings $J L$, Marin D, Neumann PJ: Prevalence and impact of medical comorbidity in Alzheimer's disease. J Gerontol A Biol Sci Med Sci 2002, 57:M173-M177.

3. Kuo TC, Zhao Y, Weir S, Kramer MS, Ash AS: Implications of comorbidity on costs for patients with Alzheimer disease. Med Care 2008, 46:839-846.

4. Leon J, Cheng CK, Neumann PJ: Alzheimer's disease care: costs and potential savings. Health Aff (Millwood) 1998, 17:206.

5. Schubert CC, Boustani M, Callahan CM, Perkins AJ, Carney CP, Fox C, Unverzagt $F$, Hui $S$, Hendrie HC: Comorbidity profile of dementia patients in primary care: are they sicker? J Am Geriatr Soc 2006, 54:104-109.

6. Richards M, Brayne C: What do we mean by Alzheimer's disease? BMJ 2010, 341:c4670.

7. Skoog I: Vascular aspects in Alzheimer's disease. J Neural Transm Suppl 2000, 59:37.

8. Savva GM, Stephan BC, Alzheimer's Society Vascular Dementia Systematic Review Group: Epidemiological studies of the effect of stroke on incident dementia: a systematic review. Stroke 2010, 41:e41-e46.

9. Biessels GJ, Staekenborg S, Brunner E, Brayne C, Scheltens P: Risk of dementia in diabetes mellitus: a systematic review. Lancet Neuro/ 2006, 5:64-74.

10. Whitmer RA, Karter AJ, Yaffe K, Quesenberry CP, Selby JV: Hypoglycemic episodes and risk of dementia in older patients with type 2 diabetes mellitus. JAMA 2009, 301:1565-1572.

11. Keenan TD, Goldacre R, Goldacre MJ: Associations between age-related macular degeneration, Alzheimer disease, and dementia: record linkage study of hospital admissions. JAMA Ophthalmol 2014, 132:63-68.

12. Sampson EL, Blanchard MR, Jones L, Tookman A, King M: Dementia in the acute hospital: prospective cohort study of prevalence and mortality. Br J Psychiatry 2009, 195:61-66.

13. Sinclair AJ, Girling AJ, Bayer AJ: Cognitive dysfunction in older subjects with diabetes mellitus: impact on diabetes self-management and use of care services. Diabetes Res Clin Pract 2000, 50:203-212.

14. Fortin M, Soubhi H, Hudon C, Bayliss EA, Van Den Akker M: Multimorbidity's many challenges. BMJ 2007, 334:1016

15. Bunn F, Goodman C, Sworn K, Rait G, Brayne C, Robinson L, McNeilly E, \|liffe S: Psychosocial factors that shape patient and carer experiences of dementia diagnosis and treatment: a systematic review of qualitative studies. PLoS Med 2012, 9:e1001331.

16. Valderas JM, Starfield B, Sibbald B, Salisbury C, Roland M: Defining comorbidity: implications for understanding health and health services. Ann Fam Med 2009, 7:357-363.

17. Arksey H, O'Malley L: Scoping studies: towards a methodological framework. Int I Soc Res Methodo/ 2005, 8:19-32

18. Levac D, Colquhoun H, O'Brien K: Scoping studies: advancing the methodology. Implement Sci 2010, 5:1-9.

19. Rumrill PD, Fitzgerald SM, Merchant WR: Using scoping literature reviews as a means of understanding and interpreting existing literature. Work 2010, 35:399-404

20. Grant MJ, Booth A: A typology of reviews: an analysis of 14 review types and associated methodologies. Health Info Libr J 2009, 26:91-108.

21. Bunn F, Goodman C, Brayne C, Norton S, Rait G, Robinson L, Schoeman J: Comorbidity and Dementia: Improving Healthcare for People with Dementia. (CoDem). 2013. http://www.nets.nihr.ac.uk/projects/hsdr/111017072013.

22. Greenhalgh T, Peacock R: Effectiveness and efficiency of search methods in systematic reviews of complex evidence: audit of primary sources. BMJ 2005, 331:1064-1065.

23. Australian Commission on Safety and Quality in Health Care: Evidence for the Safety and Quality Issues Associated with the Care of Patients with Cognitive Impairement in Acute Care Settings: a Rapid Review. Sydney: 2013.

24. Allen K, Stapleton K, McLean F: Dementia and Deafness: an Exploratory Study. Queensbury House Trust and the Scottish Executive; 2005.

25. Balfour J, O'Rourke N: Older adults with Alzheimer disease, comorbid arthritis and prescription of psychotropic medications. Pain 2003, 8:198.

26. Barnett K, Mercer SW, Norbury M, Watt G, Wyke S, Guthrie B: Epidemiology of multimorbidity and implications for health care, research, and medical education: a cross-sectional study. Lancet 2012, 380:37-43.
27. Bartlett A, Clarke B: An exploration of healthcare professionals' beliefs about caring for older people dying from cancer with a coincidental dementia. Dementia 2012, 11:559-565.

28. Bartlett $R$, McKeefry $D$ : Rethinking the experiences and entitlements of people with dementia: taking vision into account. J Care Serv Manage 2011, 5:105-114

29. Bayer AJ, Johnston J, Sinclair AJ: Impact of dementia on diabetic care in the aged. J R Soc Med 1994, 87:619-621.

30. Bruce DG, Casey GP, Grange V, Clarnette RC, Almeida OP, Foster JK, Ives FJ Davis TM: Cognitive impairment, physical disability and depressive symptoms in older diabetic patients: the Fremantle Cognition in Diabetes Study. Diabetes Res Clin Pract 2003, 61:59-67.

31. College of Optometrists: C04 Examining the Patient with Dementia or Other Acquired Cognitive Impairment. 2012. http://www.college-optometrists.org/ en/utilities/document-summary.cfm/docid/EBD5B4DA-FF52-4339B23A9DE2D8509DBE

32. Connolly A, lliffe S, Gaehl E, Campbell S, Drake R, Morris J, Martin H, Purandare N: Quality of care provided to people with dementia: utilisation and quality of the annual dementia review in general practice. Br J Gen Pract 2012, 62:e91-e98.

33. Curtis LH, Hammill BG, Qualls LG, Dimartino LD, Wang F, Schulman KA Cousins SW: Treatment patterns for neovascular age-related macular degeneration: analysis of 284380 Medicare beneficiaries. Am J Ophthalmol 2012, 153:1116-1124. e1111.

34. Dewing J, Dijk S: What is the current state of care for older people with dementia in general hospitals? A literature review. Dementia 2014 Jan 23 Epub ahead of print.

35. Doucet J, Druesne L, Capet C, Gréboval E, Landrin I, Moirot P, Micaud G: Risk factors and management of diabetes in elderly French patients. Diabetes Metab 2008, 34:574-580.

36. Feil D, Marmon T, Unutzer J: Cognitive impairment, chronic medical illness, and risk of mortality in an elderly cohort. Am J Geriatr Psychiatry 2003, 11:551-560.

37. Feil DG, Lukman R, Simon B, Walston A, Vickrey B: Impact of dementia on caring for patients' diabetes. Aging Ment Health 2011, 15:894-903.

38. Feil DG, Pearman A, Victor T, Harwood D, Weinreb J, Kahle K, Unutzer J: The role of cognitive impairment and caregiver support in diabetes management of older outpatients. Int J Psychiatry Med 2009, 39:199-214.

39. Feil DG, Zhu CW, Sultzer DL: The relationship between cognitive impairment and diabetes self-management in a population-based community sample of older adults with Type 2 diabetes. J Behav Med 2011, 35:190-199.

40. Formiga F, Fort I, Robles MJ, Riu S, Sabartes O, Barranco E, Catena J: Comorbidity and clinical features in elderly patients with dementia: differences according to dementia severity. J Nutr Health Aging 2009, $13: 423-427$

41. George J, Adamson J, Woodford H: Joint geriatric and psychiatric wards: a review of the literature. Age Ageing 2011, 40:543-548.

42. Gladman J, Porock D, Griffiths A, Clissett P, Harwood RH, Knight A, Jurgens F, Jones R, Schneider J, Kearney F: Care of Older People with Cognitive Impairment in General Hospitals. Final report NIHR Service Delivery and Organisation programme; 2012.

43. Gold M, Lightfoot LA, Hnath-Chisolm T: Hearing loss in a memory disorders clinic: a specially vulnerable population. Arch Neurol 1996, 53:922.

44. Goldberg SE, Bradshaw LE, Kearney FC, Russell C, Whittamore KH, Foster PE, Mamza J, Gladman JR, Jones RG, Lewis SA: Care in specialist medical and mental health unit compared with standard care for older people with cognitive impairment admitted to general hospital: randomised controlled trial (NIHR TEAM trial). BMJ 2013, 347:f4132

45. Guijarro R, San Roman CM, Gomez-Huelgas R, Villalobos A, Martin M, Guil M, Martinez-Gonzalez MA, Toledo JB: Impact of dementia on hospitalization. Neuroepidemiology 2010, 35:101-108.

46. Heun R, Schoepf D, Potluri R, Natalwala A: Alzheimer's disease and co-morbidity: increased prevalence and possible risk factors of excess mortality in a naturalistic 7-year follow-up. Eur Psychiatry 2013, 28:40-48.

47. Hewitt J, Smeeth L, Chaturvedi N, Bulpitt CJ, Fletcher AE: Self management and patient understanding of diabetes in the older person. Diabet Med 2010, 28:117-122.

48. Hoffmann $F$, van den Bussche $H$, Wiese B, Schon G, Koller D, Eisele M, Glaeske G, Scherer M, Kaduszkiewicz H: Impact of geriatric comorbidity and polypharmacy on cholinesterase inhibitors prescribing in dementia. BMC Psychiatry 2011, 11:190. 
49. Hill J, Hicks D, James J, Vanterpool G, Gillespie C, Fox C, Sinclair A: Diabetes and dementia guidance on practical management. In Training, Research and Education For Nurses in Diabetes and Institute of Diabetes in Older People. 2013.

50. Holmes J, Montana C, Powell G, Hewison J, House A, Mason J, Farrin A, McShane P, McParland L, Gilbody S, Young J, Keen J, Baldwin R, Burns A, Pratt H, Anderson D: Liaison Mental Health Services for Older People: A literature review, service mapping and in-depth evaluation of service models. In Produced for the National Institute for Health Research Service Delivery and Organisation programme; 2010.

51. Ishii K, Kabata T, Oshika T: The impact of cataract surgery on cognitive impairment and depressive mental status in elderly patients. Am J Ophthalmol 2008, 146:404-409.

52. Jefferis JM, Mosimann UP, Clarke MP: Cataract and cognitive impairment: a review of the literature. $\mathrm{Br} J$ Ophthalmol 2011, 95:17-23.

53. Jones R, Trigg R: Dementia and Serious Sight Loss. Occasional Paper, 11. Thomas Pocklington Trust; 2007. www.pocklington-trust.org.uk/.../Thomas\% 20Pocklington/.../OP11.pdf.

54. Lawrence V, Murray J, Ffytche D, Banerjee S: Out of sight, out of mind: a qualitative study of visual impairment and dementia from three perspectives. Int Psychogeriatr 2009, 21:511-518.

55. Löppönen MK, Isoaho RE, Räihä IJ, Vahlberg TJ, Loikas SM, Takala TI, Puolijok H, Irjala KM, Kivelä SL: Undiagnosed diseases in patients with dementia-a potential target group for intervention. Dement Geriatr Cogn Disord 2004, 18:321-329.

56. Lyketsos CG, Toone L, Tschanz J, Rabins PV, Steinberg M, Onyike CU, Corcoran C, Norton M, Zandi P, Breitner JC, Welsh-Bohmer K, Anthony J, Østbye T, Bigler E, Pieper C, Burke J, Plassman B, Green RC, Steffens DC, Klein L, Leslie C, Townsend JJ, Wyse BW, Munger R, Williams M, Cache County Study Group: Population-based study of medical comorbidity in early dementia and "cognitive impairment, no dementia (CIND)": association with functional and cognitive impairment: the Cache County Study. Am J Geriatr Psychol 2005, 13:656-664

57. MacKenzie G, Ireland S, Moore S, Heinz I, Johnson R, Sahlas D: Tailored interventions to improve hypertension management after stroke or TIAPhase II (Tims II). Stroke 2011, 42:e599.

58. McCormick WC, Kukull WA, van Belle G, Bowen JD: Symptom patterns and comorbidity in the early stages of Alzheimer's disease. J Am Geriatr SoC 1994, 42:517-521.

59. McKeefry D, Bartlett R: Improving vision and eye health care for people with dementia. Thomas Pocklington Trust; 2010. Number 8 http://www. pocklington-trust.org.uk/Resources/Thomas\%20Pocklington/Documents/ PDF/Research\%20Publications/RDP8.pdf.

60. Müther J, Abholz HH, Wiese B, Fuchs A, Wollny A, Pentzek M: Are patients with dementia treated as well as patients without dementia for hypertension, diabetes, and hyperlipidaemia? Br J Gen Pract 2010, 60:671-674.

61. Parke B, Beaith A, Slater L, Clarke AM: Contextual factors influencing success or failure of emergency department interventions for cognitively impaired older people: a scoping and integrative review. J Adv Nurs 2011, 67:1426-1448.

62. Parke B, Hunter KF, Strain LA, Marck PB, Waugh EH, McClelland AJ: Facilitators and barriers to safe emergency department transitions for community dwelling older people with dementia and their caregivers: a social ecological study. Int J Nurs Stud 2013, 50:1206-1218.

63. Rabadi MH, Rabadi FM, Edelstein L, Peterson M: Cognitively impaired stroke patients do benefit from admission to an acute rehabilitation unit. Arch Phys Med Rehabil 2008, 89:441-448.

64. Rait G, Walters K, Bottomley C, Petersen I, lliffe S, Nazareth I: Survival of people with clinical diagnosis of dementia in primary care: cohort study. BMJ 2010, 341:c3584

65. Sakurai H, Hanyu H, Kanetaka H, Sato T, Shimizu S, Hirao K, Iwamoto T: Prevalence of coexisting diseases in patients with Alzheimer's disease. Geriatr Gerontol Int 2010, 10:216-217.

66. Saposnik G, Cote R, Rochon PA, Mamdani M, Liu Y, Raptis S, Kapral MK Black SE: Care and outcomes in patients with ischemic stroke with and without preexisting dementia. Neurology 2011, 77:1664-1673.

67. Shah R, Evans BJ, Edgar D: A survey of the availability of state-funded primary eye care in the UK for the very young and very old. Ophthal Physiol Opt 2007, 27:473-481.

68. Sinclair AJ, Paolisso G, Castro M, Bourdel-Marchasson I, Gadsby R, Rodriguez Manas L: European Diabetes Working Party for Older People 2011 clinical guidelines for type 2 diabetes mellitus. Executive summary. Diabetes Metab 2011, 37:S27-S38.
69. Sloan FA, Taylor DH Jr: Effect of Alzheimer disease on the cost of treating other diseases. Alzheimer Dis Assoc Disord 2002, 16:137.

70. Spencer K, Foster P, Whittamore KH, Goldberg SE, Harwood RH: Delivering dementia care differently-evaluating the differences and similarities between a specialist medical and mental health unit and standard acute care wards: a qualitative study of family carers' perceptions of quality of care. BMJ Open 2013, 3:e004198.

71. Stenvall M, Berggren M, Lundström M, Gustafson Y, Olofsson B: A multidisciplinary intervention program improved the outcome after hip fracture for people with dementia-subgroup analyses of a randomized controlled trial. Arch Gerontol Geriatr 2012, 54:e284-e289.

72. Stephan B, Brayne C, Savva GM, Matthews FE: Occurrence of medical co-morbidity in mild cognitive impairment: implications for generalisation of $\mathrm{MCl}$ research. Age Ageing 2011, 40:501.

73. Tadros G, Salama RA, Kingston P, Mustafa N, Johnson E, Pannell R, Hashmi $\mathrm{M}$ : Impact of an integrated rapid response psychiatric liaison team on quality improvement and cost savings: the Birmingham RAID model. Psychiatrist 2013, 37:4-10

74. Thorpe CT, Thorpe JM, Kind AJ, Bartels CM, Everett CM, Smith MA: Receipt of monitoring of diabetes mellitus in older adults with comorbid dementia. J Am Geriatr Soc 2012, 60:644-651.

75. Uhlmann R, Larson E, Koepsell T, Rees T, Duckert L: Visual impairment and cognitive dysfunction in Alzheimer's disease. J Gen Intern Med 1991, 6:126-132.

76. Uhlmann RF, Larson EB, Rees TS, Koepsell TD, Duckert LG: Relationship of hearing impairment to dementia and cognitive dysfunction in older adults. JAMA 1989, 261:1916-1919.

77. Vitry Al, Roughead EE, Preiss AK, Ryan P, Ramsay EN, Gilbert AL, Caughey GE, Shakib S, Esterman A, Zhang Y: Influence of comorbidities on therapeutic progression of diabetes treatment in Australian veterans: a cohort study. PLoS One 2010, 5:e14024

78. Whitson HE, Ansah D, Whitaker D, Potter G, Cousins SW, MacDonald H, Pieper CF, Landerman L, Steffens DC, Cohen HJ: Prevalence and patterns of comorbid cognitive impairment in low vision rehabilitation for macular disease. Arch Gerontol Geriatr 2010, 50:209-212.

79. Yochim BP, Mueller AE, Kane KD, Kahook MY: Prevalence of cognitive impairment, depression, and anxiety symptoms among older adults with glaucoma. J Glaucoma 2012, 21:250-254.

80. Zamrini E, Parrish JA, Parsons D, Harrell LE: Medical comorbidity in black and white patients with Alzheimer's disease. South Med J 2004, 97:2-6.

81. Zekry D, Herrmann FR, Grandjean R, Meynet MP, Michel JP, Gold G, Krause KH: Demented versus non-demented very old inpatients: the same comorbidities but poorer functional and nutritional status. Age Ageing 2008, 37:83-89.

82. Jara M, Zhang I, Tcherny-Lessenot S, Wanju S: Less or more cataracts in Alzheimer's disease. Pharmacoepidemiol Drug Saf 2011, 20:S302-S303.

83. Zhang Y, Vitry A, Roughead E, Ryan P, Gilbert A: Co-morbidity and the utilization of health care for Australian veterans with diabetes. Diabet Med 2010, 27:65-71.

84. Guthrie B, Payne K, Alderson P, McMurdo ME, Mercer SW: Adapting clinical guidelines to take account of multimorbidity. BMJ 2012, 345:e6341.

85. Lawrence V, Murray J, Samsi K, Banerjee S: Attitudes and support needs of Black Caribbean, south Asian and White British carers of people with dementia in the UK. Br J Psychiatry 2008, 193:240-246.

86. Lawrence V, Samsi K, Banerjee S, Morgan C, Murray J: Threat to valued elements of life: the experience of dementia across three ethnic groups. Gerontologist 2010, 51:39-50.

87. Trigg R, Jones R: Dementia and Blindness: Research Findings number 6. Thomas Pocklington Trust; 2005. http://www.pocklington-trust.org.uk/ Resources/Thomas\%20Pocklington/Documents/PDF/Research\% 20Publications/RF6.pdf.

88. Bartlett D, McKeefry R: People with Dementia and Sight Loss: a Scoping Study of Models of Care, 25. Thomas Pockington Trust; 2009. http://www. pocklington-trust.org.uk/Resources/Thomas\%20Pocklington/Documents/ PDF/Research\%20Publications/RF25.pdf.

89. Lawrence F, Murray J, Banerjee S: The Experiences and Needs of People with Dementia and Serious Visual Impairment: a Qualitative Study, Volume 19. 8: Thomas Pocklington Trust; 2008:1-8. http://www.pocklington-trust.org.uk/ Resources/Thomas\%20Pocklington/Documents/PDF/Research\% 20Publications/RF19.pdf.

90. Lawrence $V$, Murray J: Balancing independence and safety: the challenge of supporting older people with dementia and sight loss. Age Ageing 2010, 39:476-480 
91. Allan K: Deafness and dementia: consulting on the issues. J Dement Care 2006, 14:35.

92. Connolly A, Campbell S, Gaehl E, lliffe S, Drake R, Morris J, Martin H, Purandare N: Under-provision of medical care for vascular diseases for people with dementia in primary care: a cross-sectional review. $\mathrm{Br} J \mathrm{Gen}$ Pract 2013, 63:e88-e96.

93. Piette JD, Kerr EA: The impact of comorbid chronic conditions on diabetes care. Diabetes Care 2006, 29:725-731.

94. Kerr EA, Heisler M, Krein SL, Kabeto M, Langa KM, Weir D, Piette JD: Beyond comorbidity counts: how do comorbidity type and severity influence diabetes patients' treatment priorities and self-management? I Gen Intern Med 2007, 22:1635-1640

doi:10.1186/s12916-014-0192-4

Cite this article as: Bunn et al:: Comorbidity and dementia: a scoping review of the literature. BMC Medicine 2014 12:192.

\section{Submit your next manuscript to BioMed Central and take full advantage of:}

- Convenient online submission

- Thorough peer review

- No space constraints or color figure charges

- Immediate publication on acceptance

- Inclusion in PubMed, CAS, Scopus and Google Scholar

- Research which is freely available for redistribution 